\title{
Detection of Metabolite Changes in C6 Glioma Cells Cultured with Antimitotic Oleyl Glycoside by ${ }^{1}$ H MAS NMR
}

\author{
Isabel García-Álvarez, ${ }^{\dagger}$ Leoncio Garrido, ${ }^{\ddagger}$ Ernesto Doncel-Pérez, ${ }^{\dagger}$ Manuel Nieto-Sampedro, ${ }^{\dagger, \S}$ and \\ Alfonso Fernández-Mayoralas*,॥ \\ Instituto de Química Orgánica General, CSIC, Juan de la Cierva 3, 28006 Madrid, Spain, Hospital Nacional de Parapléjicos, SESCAM, \\ Finca la Peraleda s/n, 45071 Toledo, Spain, Instituto de Ciencia y Tecnología de Polímeros, CSIC, Juan de la Cierva 3, 28006 Madrid, Spain, \\ Instituto Cajal, CSIC, Avenida Doctor Arce 37, 28002 Madrid, Spain
}

Received October 9, 2008

The synthetic glycoside, oleyl $N$-acetyl- $\alpha$-D-glucosaminide (1), was previously shown to exhibit antimitotic activity on rat (C6) and human (U-373) glioma lines. To obtain information about its mechanism of action, metabolite changes in C6 glioma cells were analyzed after treatment with $\mathbf{1}$ using high-resolution magic angle spinning ${ }^{1} \mathrm{H}$ NMR. Compound $\mathbf{1}$ caused either a decrease or an increase in the intensity of the signal assigned to coenzyme A (CoA) metabolites depending on the concentration used. The data obtained from the ${ }^{1} \mathrm{H}$ NMR spectra of cells cultured with $\mathbf{1}$, combined with those obtained after treatment with oleic acid (an inhibitor of acetyl-CoA carboxylase) and phenyl butyrate (a known antineoplastic agent), suggest that 1 may be altering the metabolism of fatty acids and induce apoptosis of C6 glioma cells. These results point to NMR spectroscopy as an efficient technique for monitoring the response of the cells to therapeutic agents.

\section{Introduction}

The treatment of glioma has yielded only meager increases in survival time in spite of important advances in therapeutic oncology. Only half of the patients receiving standard treatment for brain tumor in the U.S. survived one year after diagnosis. ${ }^{1}$ The investigation of synthetic compounds able to slow down glioma progression is, therefore, of great interest.

The presence in brain extracts of inhibitors of astroblast and astrocytoma division was first described by one of us. ${ }^{2}$ On the basis of structural elements of the natural inhibitor, we synthesized series of oligo- and monosaccharides, which were tested as inhibitors of brain tumor cell division. ${ }^{3-7}$ Recently we have obtained a family of $\mathrm{N}$-acyl-glucosamine derivatives, some of which showed antimitotic activity against rat C6 glioma cells with low $\mathrm{IC}_{50}$ values. $^{7}$ The results obtained indicated that the activity was increased by a long hydrocarbon chain at position $\mathrm{C}-1$ of the glucosamine backbone, the most inhibitory compound being the oleyl glycoside $\mathbf{1}$ (Chart 1).

Because of the high antiproliferative activity exhibited by $\mathbf{1}$, it was of interest to obtain information about its mode of action, which could be of great value in designing new compounds with improved therapeutic properties. With this purpose, we have analyzed changes in low molecular weight metabolites after treatment of C6 glioma cells with 1 using high-resolution magic angle spinning (HR-MAS) ${ }^{1} \mathrm{H}$ NMR.

The NMR approach used to study liquids (i.e., body fluids and tissue extracts) leads to poorly resolved proton spectra when it is applied to investigate intact cells and tissues. The main

* To whom correspondence should be addressed. Phone: 349156229 00. Fax: 349156448 53. E-mail: mayoralas@iqog.csic.es.

\footnotetext{
${ }^{\dagger}$ Hospital Nacional de Parapléjicos, SESCAM.

* Instituto de Ciencia y Tecnología de Polímeros, CSIC.

$\S$ Instituto Cajal, CSIC.

"Instituto de Química Orgánica General, CSIC.
}

Chart 1. Structure of Antimitotic Glycoside 1

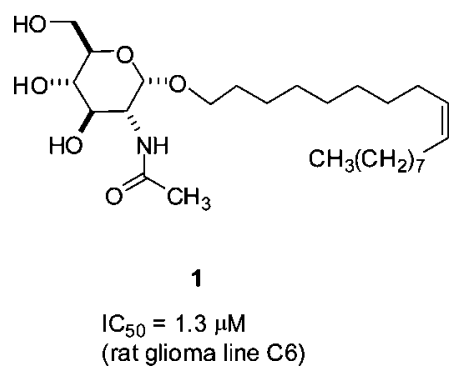

two factors contributing to the observed peak broadening are the chemical and physical heterogeneity present in these samples. Thus, they have a wide variety of metabolites with functional groups having their chemical shifts overlapping in a relatively narrow region of the proton spectrum. The heterogeneous nature of the samples also results in regional differences in magnetic susceptibility that give rise to local field gradients and, consequently, to a dispersion of the spectral frequencies associated to each chemical moiety. Additional causes of line broadening are the residual dipolar spin interactions and chemical shift anisotropy. The restricted or anisotropic molecular motion in solid-like samples, such as those of interest in this work, hampers the reduction of these contributions to the resonance linewidths, as it occurs in liquids where the rapid isotropic molecular motion averages them to zero. One approach to reduce or minimize the contribution of the interactions indicated above to the peak broadening involves spinning the sample sufficiently fast at an angle $\theta=54^{\circ} 44^{\prime}$ relative to the spectrometer static magnetic field $\mathrm{B}_{0}$ (i.e., the "magic-angle" where contributions proportional to: $\left.3 \cos ^{2} \theta-1=0\right) .{ }^{8-10}$ In this regard, proton MAS NMR combined with $\mathrm{T}_{2}$-filtering has been used to narrow the resonances from small molecules and improve the resolution of intact cells and tissues spectra, 
allowing weak resonances associated with metabolites present at low concentrations to be revealed. ${ }^{11-15}$ The nondestructive nature of the technique allows the acquisition of metabolic information directly from cells with minimal preparation and their analysis by other methods. In addition, the solid state approach offers the advantage over conventional liquid state NMR (i.e., used in analysis of cells extracts) of simultaneous observation of lipophilic and hydrophilic metabolites.

One of the pathologies that have been widely studied by NMR is brain cancer. The spectral pattern of glioblastomas and cultured glioma cell lines have been studied using NMR spectroscopy ${ }^{16-18}$ in an attempt to detect or predict its progression. Here, we show that the analysis of the ${ }^{1} \mathrm{H}$ NMR spectra of $\mathrm{C} 6$ cells cultured in the presence of $\mathbf{1}$ has provided clues to its mechanism of action. Because the main contribution to line broadening in our case is due to magnetic susceptibility differences between intracellular structures, slow spinning rates are sufficient to greatly improve spectral resolution. ${ }^{10,19}$ Thus, proton HR-MAS NMR spectra were acquired at moderate spinning rates, enough to avoid the interference of spinning side bands in the spectral region of interest while minimizing sample heating and disruption of cell membranes. ${ }^{11,19}$ Furthermore, a $\mathrm{T}_{2}$-filter was used to reduce the interference of macromolecular protons, including contribution from broad lipid resonances, enabling nonlipid metabolites to be readily identified. Our results show that proton HR-MAS NMR spectroscopy is an effective tool for monitoring the response of the cells to therapeutic agents.

\section{Results and Discussion}

In our previous report, ${ }^{7}$ we obtained compound $\mathbf{1}$ in a single reaction step by Fisher type glycosylation of oleic alcohol with $\mathrm{N}$-acetyl-D-glucosamine in the presence of $\mathrm{BF}_{3} \cdot \mathrm{OEt}_{2}$, although in a low yield (10\%). After evaluating several conditions and acid promoters, we improved the synthetic procedure by using $\mathrm{H}_{2} \mathrm{SO}_{4}$ adsorbed on silica ${ }^{20}$ as catalyst, which afforded $\mathbf{1}$ in $38 \%$ yield. This procedure presents the advantage of using a solid catalyst, which is easier and safer to handle than $\mathrm{BF}_{3} \cdot \mathrm{OEt}_{2}$.

Proton T2-filtered MAS NMR spectroscopy was used to study the effect of 1 on C6 metabolic profile. The T2-filter consisted of a CPMG pulse sequence with $90^{\circ} \mathrm{rf}$ pulse followed by a train of thirty $180^{\circ} \mathrm{rf}$ pulses spaced $2 \mathrm{~ms}$ apart. The effective echo time was $60 \mathrm{~ms}$. In addition, to suppress the water protons signal, low power continuous irradiation rf during the waiting period was applied.

The ${ }^{1} \mathrm{H}$ NMR spectra of C6 glioma cells after $24 \mathrm{~h}$ of incubation is shown in Figure 1a. The assignment of relevant signals was based on the chemical shifts reported for metabolites of cultured glioma cell lines. ${ }^{18,21}$ Thus, the peak centered at $3.23 \mathrm{ppm}$ was assigned to the total choline trimethyl resonance (tCho) and consists of at least three different choline subspecies (choline, glycerophophocholine, and phosphocholine). A broad peak at $1.3 \mathrm{ppm}$ is due to the resonances from lipid methylene groups and from lactate methyl group. The resonance at the lowest chemical shift, $0.67 \mathrm{ppm}$, corresponds to one of the methyl groups of the isopropyliden moiety of coenzyme A (CoA) metabolites, although contribution of the methyl group of cholesterol cannot be excluded. The assignment of this signal is facilitated by its occurrence in a relatively uncrowded region and well-separated from the peak at $0.9 \mathrm{ppm}$ containing the resonances from methyl groups of lipids and proteins. The presence of a relatively intense peak of CoA metabolites can be associated to the fact that tumors in general, and this cell line in particular, ${ }^{18}$ undergo exacerbated de novo biogenesis of

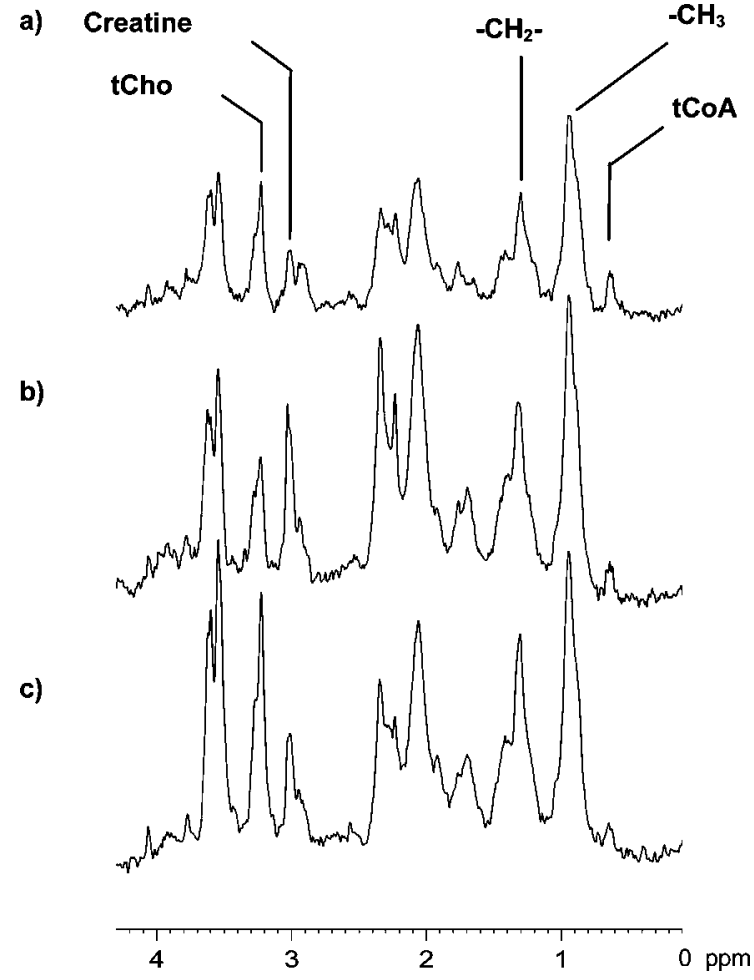

Figure 1. NMR spectra $24 \mathrm{~h}, \mathrm{~T}_{2}=60 \mathrm{~ms}, \mathrm{~ns}=500$. (a) C6 control. (b) $\mathrm{C} 6+1(10 \mu \mathrm{M})$. (c) $\mathrm{C} 6+$ oleic acid $(100 \mu \mathrm{M})$. tCho, total choline trimethyl resonance; tCoA, total coenzyme A methyl resonance.

Scheme 1. Schematic Representation of Fatty Acid Biosynthesis $^{a}$

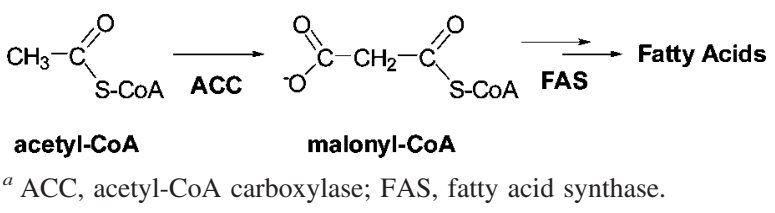

fatty acids, a process that is necessary to maintain a constant supply of lipids and lipid precursors to fuel membrane production. During lipogenesis, tumor cells present high steady state levels of malonyl-CoA (Scheme 1). Therefore, this metabolite must be the main compound contributing to the signal at 0.67 ppm.

The most significant metabolic change detected by ${ }^{1} \mathrm{H}$ NMR spectroscopy after treatment with $1(10 \mu \mathrm{M})$ for $24 \mathrm{~h}$ was the decrease in the signal at $0.67 \mathrm{ppm}$ from CoA metabolites (Figure 1b). This reduction was quantified using the resonance from creatines, which is centered at $3.00 \mathrm{ppm}$. Creatine is a commonly used internal concentration reference for in vivo ${ }^{1} \mathrm{H} \mathrm{NMR}^{21}$ because its concentration correlates with the number of metabolically active cells and is used as a measure of viable cell count. Thus, the ratio $\mathrm{CoA} /$ creatine in the controls was $0.78 \pm$ 0.07 , while in treated cells was $0.32 \pm 0.07$. Considering the biosynthetic route in Scheme 1, the reduction of the intensity of this peak suggests that $\mathbf{1}$ could be inhibiting the synthesis of fatty acid at the step of malonyl-CoA formation, namely the carboxylation of acetyl-CoA. A recent report showed that oleic acid strongly reduced acetyl-CoA carboxylase activity and was an inhibitor of fatty acid synthesis in C6 glioma cells. ${ }^{22}$ Interestingly, compound $\mathbf{1}$ is a glycoside of oleyl alcohol, and the presence of the oleyl group was the main structural difference with respect to the parent glycosides that resulted less inhibitory of glioma cell division than 1 . $^{7}$ The treatment of 


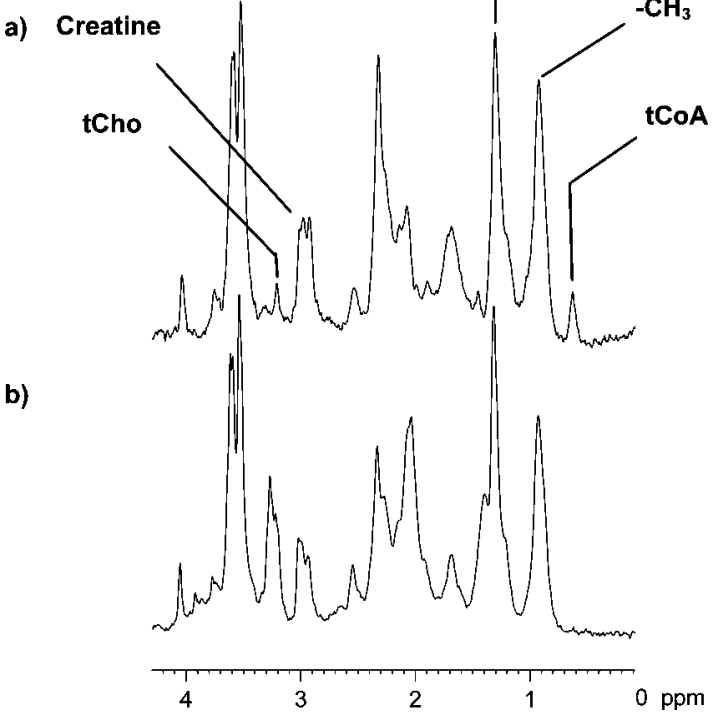

Figure 2. NMR spectra $48 \mathrm{~h}, \mathrm{~T}_{2}=60 \mathrm{~ms}$, ns $=1000$. (a) C6 control. (b) $\mathrm{C} 6+\mathbf{1}(10 \mu \mathrm{M})$.

C6 cells with oleic acid $(100 \mu \mathrm{M})$ for $24 \mathrm{~h}$ afforded a ${ }^{1} \mathrm{H}$ NMR spectrum similar to that obtained with $\mathbf{1}(10 \mu \mathrm{M})$ (Figure 1c), in which the major metabolic change was also the intensity of the signal at $0.67 \mathrm{ppm}$. In this case, a 3 -fold decrease in the peak intensity from CoA metabolites was observed. The parallel behavior of $\mathbf{1}$ and oleic acid seems to indicate that the glycoside could also be inhibiting acetyl-CoA carboxylase activity.

Longer incubation ( $48 \mathrm{~h}$ ) with 1 gave a spectrum in which no signal for CoA metabolites was observed and the concentration of choline-containing metabolites was increased as compared to control (Figure 2). The choline signal in 1-treated cells increased more than 3 -fold, considering the peak of creatine as reference $(2.47 \pm 1.14$ versus $0.72 \pm 0.37$ for treated and control cells, respectively). It has been reported that in the early phase of programmed cell death in rat brain glioma, the concentration of choline metabolites increases, as determined by ${ }^{1} \mathrm{H}$ NMR spectroscopy. ${ }^{23}$ This increase may reflect altered metabolism as a result of choline kinase activation accompanied by simultaneous membrane breakdown through phospholipases. In addition, a slight increase of the signal intensity at $1.3 \mathrm{ppm}$, assigned to the methylene protons of mobile lipids, was observed. An association between lipid body formation and cell death has been demonstrated in a number of drug-treated cell models. ${ }^{24}$ Therefore, the ${ }^{1} \mathrm{H}$ NMR spectrum after treatment with $10 \mu \mathrm{M}$ of $\mathbf{1}$ for $48 \mathrm{~h}$ suggests that a certain number of glioma cells entered apoptosis.

The typical characteristics of apoptotic cell death were verified by the analysis of DNA fragmentation induced by $\mathbf{1}$. Figure 3 shows that the incubation of C6 cells with $80 \mu \mathrm{M}$ of 1 resulted in DNA laddering after $19 \mathrm{~h}$ of incubation, demonstrating that cell death was indeed an apoptotic and not a necrotic process. A high ratio of DNA fragmentation was already observed with $40 \mu \mathrm{M}$ of 1 , while no appreciable DNA fragmentation was observed at $10 \mu \mathrm{M}$ after $19 \mathrm{~h}$. The latter suggests that the previously discussed changes in the ${ }^{1} \mathrm{H}$ NMR spectrum of cells after $48 \mathrm{~h}$ incubation with $10 \mu \mathrm{M}$ correspond to the apoptotic signals for a small population of cells.

In view of these results, the ${ }^{1} \mathrm{H}$ NMR spectra of cells cultured at higher concentrations of $\mathbf{1}$ were registered. The spectrum of cells treated with $40 \mu \mathrm{M}$ of $\mathbf{1}$ shows a decline of the intensity

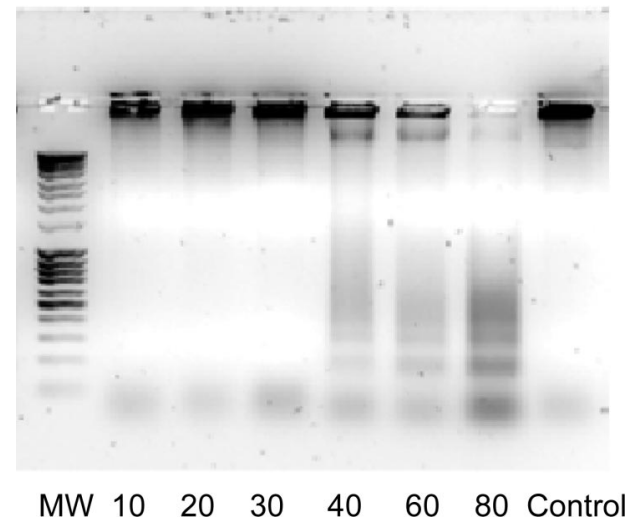

Figure 3. DNA fragmentation of C6 cells treated with $\mathbf{1}$ at different concentrations $(\mu \mathrm{M})$.

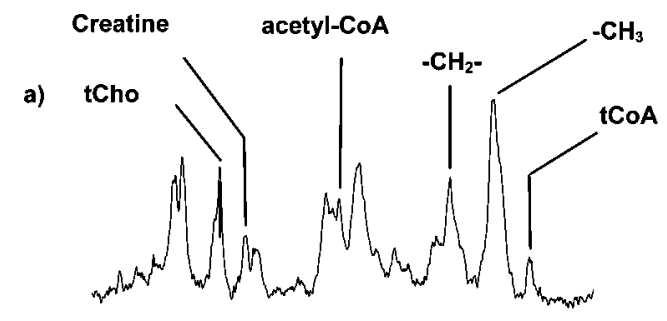

b)

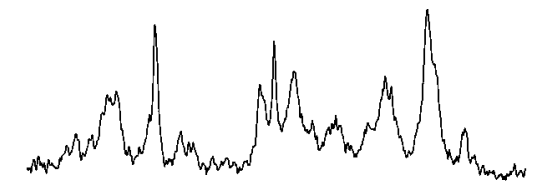

c)

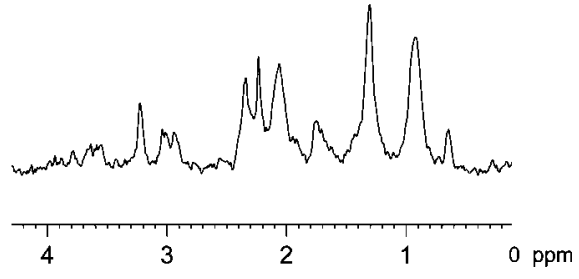

Figure 4. NMR spectra $24 \mathrm{~h}, \mathrm{~T}_{2}=60 \mathrm{~ms}$, ns $=500$. (a) C6 control. (b) $\mathrm{C} 6+\mathbf{1}(40 \mu \mathrm{M})$. (c) $\mathrm{C} 6+\mathrm{PB}(10 \mathrm{mM})$.

of all the signals (Figure 4b), indicating a decrease in cell population density due to the inhibitory effect of $\mathbf{1}$, with a high ratio of cell death as shown by the small intensity of the peak from creatine. Experiments performed at even higher concentrations (i.e., $100 \mu \mathrm{M}$; data not shown) lead to very small number of viable cells hampering any quantitative analysis. These results were anticipated in view of findings from DNA fragmentation experiments. In addition, the signal for CoA metabolites at 0.67 ppm was significantly high, in contrast to the effect observed when the incubation was performed with $10 \mu \mathrm{M}$ of $\mathbf{1}$, namely the disappearance of this signal. It has been postulated that under stress conditions glioma cells used the fatty acid oxidation as protective mechanism. ${ }^{25}$ Under this hypothesis, we reasoned that at $40 \mu \mathrm{M}$ concentration of 1 , when cell death occurs, the oxidation of fatty acids is taking place. During the oxidative process high levels of acetyl-CoA are formed. In this sense, the presence of a sharp peak at $2.24 \mathrm{ppm}$ ascribed to the acetyl group of acetyl-CoA confirmed the assignment of this metabolite. To check whether the resonances from this metabolite are indicative of a cell death process, cells were treated with phenylbutyrate (PB), a chemotherapeutic agent that has been 
<smiles>CCCCCCCC=CC(O)C(CO)NC(=O)CCCCCCCCCCCCCCCCCCCCCCCC</smiles><smiles>CCCCCCCC/C=C\CCCCCCCC(=O)NC(CO)CO</smiles>

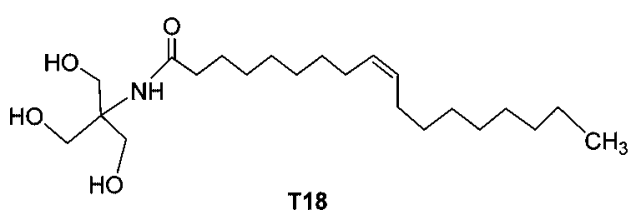

Figure 5. Structure of ceramide analogues S18 and T18 known to induce apoptosis (ref 28).

shown to induce apoptosis in certain malignant cells. ${ }^{26,27}$ The ${ }^{1} \mathrm{H}$ NMR spectrum after incubation with PB (10 mM) for $24 \mathrm{~h}$ showed also a profile for low cell density and viability and, additionally, a significant accumulation of mobile lipids (Figure $4 c)$. In agreement with our expectation, a high increased of the signals assigned to acetyl-CoA was also observed (peaks at 2.24 and $0.67 \mathrm{ppm})$.

The data obtained from the ${ }^{1} \mathrm{H}$ NMR spectra of the different experiments suggest that $\mathbf{1}$ may inhibit cell division at concentrations around $10 \mu \mathrm{M}$ (the $\mathrm{IC}_{50}$ value for $\mathbf{1}$ was $\left.1.4 \mu \mathrm{M}\right)^{7}$ by inhibiting de novo synthesis of fatty acids. At higher concentrations (above $40 \mu \mathrm{M}$ ), a significant ratio of cell death occurred through an apoptotic process. The mechanism by which apoptosis takes place would be the objective of our future investigations. In this context, it is worth mentioning that $\mathbf{1}$ shares structural elements with ceramide analogues S18 and T18, which have been shown to induce apoptosis (Figure 5). ${ }^{28}$ The proapoptotic activity required the presence of at least two hydroxy alkyl branches and an amido-linkage to the fatty (oleic) acid chain. The authors suggested that these compounds could be acting directly at the apoptotic targets for ceramide.

In conclusion, the present work shows for the first time to our knowledge that intensity of the signals associated to CoA metabolites in the HR-MAS ${ }^{1} \mathrm{H}$ NMR spectrum of intact glioma cells are significantly affected by an antitumoral agent that induces apoptosis. The decrease or increase in intensity of peaks assigned to CoA metabolites seems to be related to either the inhibition of lipid synthesis or the activation of lipid oxidation, respectively. The current interest ${ }^{29,30}$ concerning the role of lipid synthesis in cancer progression makes this observation of special relevance.

Our results, supported by others using structurally related molecules, point out that the conjugation of an oleyl moiety with a sugar can result in compounds able to inhibit cell division and induce cell death in glioma cell lines, raising expectations to generate promising candidates to treat one of the most deadly forms of cancer.

\section{Experimental Section}

Chemistry. General Methods. Thin-layer chromatography (TLC) was performed on aluminum sheets $60 \mathrm{~F}_{254}$ Merck silica gel, and compounds were visualized by irradiation with UV light and/or by treatment with a solution of $\mathrm{Ce}_{2} \mathrm{MoO}_{4}$ or $5 \% \mathrm{H}_{2} \mathrm{SO}_{4}$ in $\mathrm{EtOH}$, followed by heating. Flash column chromatography was performed using thick walled column, employing silica gel (Merck 60: $0.040-0.063 \mathrm{~mm}$ ). The eluent used is indicated, and solvent ratios refer to volume. Optical rotation was recorded on a PerkinElmer 241 polarimeter $(\lambda=589 \mathrm{~nm}, 1 \mathrm{dm}$ cell $)$. The purity of compound 1 was $\geq 95 \%$ as determined by combustion analysis, recorded on a Heraus CHN-O Rapid analyzer.

Oleyl 2-acetamido-2-deoxy- $\alpha$-D-glucopyranoside (1). For the preparation of the acid catalyst, ${ }^{20} 10 \mathrm{~g}$ of silica gel (200-325 mesh) were suspended in diethyl ether $(50 \mathrm{~mL})$ and concentrated $\mathrm{H}_{2} \mathrm{SO}_{4}$ $(3 \mathrm{~mL})$ was slowly added dropwise under agitation. During the adsorption process, over $10 \mathrm{~min}$, the suspension was gently shaken at room temperature. Then the solvent was removed by flash distillation at $60^{\circ} \mathrm{C}$ under reduced pressure and the silica was dried at $60{ }^{\circ} \mathrm{C}$ under reduced pressure $(2-4 \mathrm{mbar})$ for $3 \mathrm{~h}$. Afterward, $\mathrm{N}$-acetyl glucosamine $(500 \mathrm{mg}, 2.26 \mathrm{mmol})$ and $85 \%$ oleic alcohol (4.1 $\mathrm{mL}, 11.3 \mathrm{mmol})$ were dissolved in nitromethane $(2 \mathrm{~mL})$ under argon and $\mathrm{H}_{2} \mathrm{SO}_{4}$ adsorbed on silica $(50 \mathrm{mg})$ was added. The reaction mixture was stirred at $100{ }^{\circ} \mathrm{C}$ for $4 \mathrm{~h}$. After this time elapsed, the reaction mixture was cooled down to room temperature, the solvent was removed by flash distillation, and the residue was purified by silica gel column chromatography (ethyl acetate-methanol, $10: 0 \rightarrow 10: 1)$ to give $1(404 \mathrm{mg}, 38 \%)$. $[\alpha]_{\mathrm{D}}:+103.1^{\circ}$ (c 0.95 , $\mathrm{MeOH}) .{ }^{1} \mathrm{H}$ and ${ }^{13} \mathrm{C}$ NMR spectrum was identical to that previously described. $^{7}$

Cell Culture. Rat C6 glioma cells were from the American Type Culture Collection. DMEM cell culture medium, penicillin (100 $\mathrm{U} / \mathrm{mL})$, and streptomycin $(100 \mu \mathrm{g} / \mathrm{mL})$ were all purchased from Sigma-Aldrich (Steinheim, Germany) and supplemented with $10 \%$ Linus fetal calf serum (FCS) from Cultek (Madrid, Spain). The cell cultures were maintained in a humidified atmosphere of $5 \%$ $\mathrm{CO}_{2}$ at $37^{\circ} \mathrm{C}$.

The C6 cells were seeded on plastic flasks at a density of $2 \times$ $10^{5}$ cells $/ \mathrm{cm}^{2}$ and allowed to attach for $6 \mathrm{~h}$. After the cells were attached to the substrate, the medium was changed to DMEM without serum and the cells were incubated for $24 \mathrm{~h}$. Then medium was replaced by DMEM plus $1 \%$ FCS containing the test compounds. The cell cultures were incubated for 24 or $48 \mathrm{~h}$, harvested, centrifuged, and suspended in cold phosphate buffer solution (PBS) for further analysis. Each experiment was made by triplicate, and cells without any compound were used as control.

DNA Fragmentation Assay. To examine the fragmentation of DNA, the treated and control C6 cells were centrifuged at $800 \mathrm{~g}$ for $10 \mathrm{~min}$. Cell pellets were homogenized in $1 \mathrm{~mL}$ of TRIzol Reagent (Invitrogen, Madrid, Spain), and DNA isolation protocol recommended by suppliers was followed. Briefly, chloroform was added to homogenized samples and centrifuged by $15 \mathrm{~min}$ at $10000 \mathrm{~g}$ in a microcentrifuge (Eppendorf, Hamburg, Germany). The DNA was isolated from interphase and organic phase and precipitated with $100 \%$ ethanol. The DNA pellet was washed two times with solution containing $0.1 \mathrm{M}$ sodium citrate in $10 \%$ ethanol, suspended in $75 \%$ ethanol, and centrifuged at $2000 g$. The resulting DNA pellet was dissolved in $8 \mathrm{mM} \mathrm{NaOH}$ and adjusted to $\mathrm{pH}=8.0$ with $\mathrm{TE}$ solution. DNA samples were incubated with RNase A (final $1 \mathrm{mg}$ ) $\mathrm{mL}$ ) by $1 \mathrm{~h}$ at $37^{\circ} \mathrm{C}$ and then with proteinase $\mathrm{K}$ (final $1 \mathrm{mg} / \mathrm{mL}$ ) at $37{ }^{\circ} \mathrm{C}$ for another $1 \mathrm{~h}$. The samples were analyzed by electrophoresis in $1.5 \%$ agarose gel, stained previously with SYBR Safe DNA gel stain (Invitrogen, Molecular Probes, Oregon) and finally visualized under UV light.

NMR Spectroscopy. High-resolution proton MAS NMR measurements were performed on a Bruker Avance 400 wide bore (89 $\mathrm{mm} \varnothing)$ spectrometer (Bruker Instruments, Karlsruhe, Germany) operating at 9.4 $\mathrm{T}$ (proton Larmor frecuency at $400.14 \mathrm{MHz}$ ). All spectra were acquired at $20{ }^{\circ} \mathrm{C}(293 \mathrm{~K})$ using a Bruker doubletuned broadband solid state CP/MAS probe head. After incubating the cells in the medium with the corresponding compound, they were washed with deuterated phosphate buffered solution and centrifuged to form pellets. Typically, for each sample approximately $60 \mu \mathrm{L}$ of cell pellets were placed into a $4 \mathrm{~mm} \varnothing$ zirconia rotor. The spectra were acquired using a $90^{\circ}$ pulse of 3.35 
$\mu$ s followed by a $T_{2}$ filter of $60 \mathrm{~ms}$. On selected samples (data not shown), spectra were acquired varying the $\mathrm{T}_{2}$ filter between 30 and $600 \mathrm{~ms}$. The filter of $60 \mathrm{~ms}$ was chosen as the best compromise between total acquisition time, signal-to-noise ratio, and spectral resolution. The spinning rate was $2.4 \mathrm{kHz}$. The spectral width was $8.3 \mathrm{kHz}, 16 \mathrm{k}$ data points, and the number of scans varied between 500 and 1000 with a repetition rate of $5 \mathrm{~s}$. The residual water signal was suppressed by presaturation on the water resonance. All FIDs were processed with a $2 \mathrm{~Hz}$ line broadening and the chemical shifts referenced to internal DSS ( $5 \mu \mathrm{L}$ of a $10 \mathrm{mM}$ solution) $(0.00 \mathrm{ppm})$.

Acknowledgment. Financial support provided by the Servicio de Salud de Castilla La Mancha Community (SESCAM), CSIC (PIF, 200580F0062) and the Ministry of Educación y Ciencia (CTQ2007-67403/BQU) is greatly appreciated.

\section{References}

(1) Friedman, H. S.; Szalavitz, M. What is "hope" for a patient with a deadly brain tumor? Cerebrum: DANA Forum brain Sci. 2003, 5, 7 18.

(2) Nieto-Sampedro, M. Astrocyte mitogen inhibitor related to epidermal growth factor receptor. Science 1988, 240, 1784-1786.

(3) Santos-Benito, F. F.; Fernández-Mayoralas, A.; Martín-Lomas, M.; Nieto-Sampedro, M. Inhibition of proliferation of normal and transformed cells by blood group-related oligosaccharides. J. Exp. Med. 1992, 176, 915-918

(4) Coterón, J. M.; Singh, K.; Asensio, J. L.; Domínguez-Dalda, M.; Fernández-Mayoralas, A.; Jiménez-Barbero, J.; Martín-Lomas, M.; Abad-Rodríguez, J.; Nieto-Sampedro, M. Oligosaccharides structurally related to E-selectin ligands are inhibitors of neural cell division: Synthesis, conformational analysis, and biological activity. J. Org. Chem. 1995, 60, 1502-1519.

(5) Aguilera, B.; Romero-Ramirez, L.; Abad-Rodriguez, J.; Corrales, G.; Nieto-Sampedro, M.; Fernández-Mayoralas, A. Novel disaccharide inhibitors of human glioma cell division. J. Med. Chem. 1998, 41, 4599-4606.

(6) Fernandez-Mayoralas, A.; De La Figuera, N.; Zurita, M.; Vaquero, J.; Abraham, G. A.; San Román, J.; Nieto-Sampedro, M. Central neural tumor destruction by controlled release of a synthetic glycoside dispersed in a biodegradable polymeric matrix. J. Med. Chem. 2003, 46, 1286-1288.

(7) García-Álvarez, I.; Corrales, G.; Doncel-Pérez, E.; Muñoz, A.; NietoSampedro, M.; Fernández-Mayoralas, A. Design and synthesis of glycoside inhibitors of glioma and melanoma growth. J. Med. Chem. 2007, 50, 364-373.

(8) Maricq, M. M.; Waugh, J. S. NMR in rotating solids. J. Chem. Phys. 1979, $70,3300-3316$.

(9) VanderHart, D. L.; Earl, W. L.; Garroway, A. N. Resolution in ${ }^{13} \mathrm{C}$ NMR of organic solids using high-power ${ }^{1} \mathrm{H}$ decoupling and magicangle sample spinning. J. Magn. Reson. 1981, 44, 361-401.

(10) Garroway, A. N. Magic-angle sample spinning of liquids. J. Magn. Reson. 1982, 49, 168-171

(11) Cheng, L. L.; Lean, C. L.; Bogdanova, A.; Wright, S. C.; Ackerman, J. L.; Brady, T. J.; Garrido, L. Enhanced resolution of proton NMR spectra of malignant nodes using magic angle spinning. Magn. Reson. Med. 1996, 36, 653-658.

(12) Bollard, M. E.; Garrod, S.; Holmes, E.; Lindon, J. C.; Humpfer, E.; Spraul, M.; Nicholson, J. K. High-resolution H-1 and H-1-C-13 magic angle spinning NMR spectroscopy of rat liver. Magn. Reson. Med. 2000, 44, 201-207.

(13) Calabi, L.; Paleari, L.; Biondi, L.; Linati, L.; De Miranda, M.; Ghelli, S. Application of $\mathrm{H}-1$ and $\mathrm{Na}-23$ magic angle spinning NMR spectroscopy to define the HRBC up-taking of MRI contrast agents.
J. Magn. Reson. 2003, 164, 28-34.

(14) Schiller, J.; Huster, D.; Fuchs, B.; Naji, L.; Kaufmann, J.; Arnold, K. Evaluation of cartilage composition and degradation by high-resolution magic-angle spinning nuclear magnetic resonance. Methods Mol. Med. 2004, 101, 267-286.

(15) Mahon, M. M.; deSouza, N. M.; Dina, R.; Soutter, W. P.; Mclndoe, G. A.; Williams, A. D.; Cox, I. J. Preinvasive and invasive cervical cancer: an ex vivo proton magic angle spinning magnetic resonance spectroscopy study. NMR Biomed. 2004, 17, 144-153.

(16) Preul, M. C.; Caramanos, Z.; Collins, D. L.; Villemure, J.-G.; Leblanc, R.; Olovier, A.; Pokrupa, R.; Arnol, D. L. Accurate, non-invasive diagnosis of human brain tumours by using proton magnetic resonance spectroscopy. Nat. Med. 1996, 2, 323-325.

(17) Tate, A. R.; Griffiths, J. R.; Martínez-Pérez, I.; Moreno, A.; Barba, I.; Cabañas, M. E.; Watson, D.; Alonso, J.; Bartomeus, F.; Isamat, F.; Ferrer, I.; Vila, F.; Ferrer, E.; Capdevila, A.; Arús, C. Towards a method for automated classification of ${ }^{1} \mathrm{H}$ MRS spectra from brain tumours. NMR Biomed. 1998, 11, 177-191.

(18) Quintero, M.; Cabañas, M. E.; Arús, C. A posible cellular explanation for the NMR-visible mobile lipid (ML) changes in cultured C6 glioma cells with growth. Biochim. Biophys. Acta 2007, 1771, 31-44.

(19) Wind, R. A.; Hu, J. Z. In vivo and ex vivo high-resolution 1H NMR in biological systems using low-speed magic angle spinning. Prog. NMR Spectrosc. 2006, 49, 207-259.

(20) Roy, B.; Mukhopadhyay, B. Sulfuric acid immobilized on silica: an excellent catalyst for Fischer type glycosylation. Tetrahedron Lett. 2007, 48, 3783-3787.

(21) Govindaraju, V.; Young, K.; Maudsley, A. A. Proton NMR chemical shifts and coupling constants for brain metabolites. NMR Biomed. 2000, $13,129-153$.

(22) Natali, F.; Siculella, L.; Salvati, S.; Gnoni, G. V. Oleic acid is a potent inhibitor of fatty acid and cholesterol synthesis in C6 glioma cells. $J$. Lipid Res. 2007, 48, 1966-1975.

(23) Valonen, P. K.; Griffin, J. L.; Lehtimäki, K. K.; Liimatainen, T.; Nicholson, J. K.; Gröhn, O. H. J.; Kauppinen, R. A. High-resolution magic-angle-spinning $1 \mathrm{H}$ NMR spectroscopy reveals different responses in choline-containing metabolites upon gene therapy-induced programmed cell death in rat brain glioma. NMR Biomed. 2005, 18, $252-259$.

(24) Kettonen, M. I.; Brindle, K. M. Apoptosis detection using magnetic resonance imaging and spectroscopy. Prog. Nucl. Magn. Reson. Spectrosc. 2005, 47, 175-185.

(25) Guzmán, M.; Blázquez, C. Ketone body synthesis in the brain: possible neuroprotective effects. Prostaglandins, Leukotrienes Essent. Fatty Acids. 2004, 70, 287-292.

(26) DiGiuseppe, J. A.; Weng, L. J.; Yu, K. H.; Fu, S.; Kastan, M. B.; Samid, D.; Gore, S. D. Phenylbutyrate-induced G1 arrest and apoptosis in myeloid leukemia cells: Structure-function analysis. Leukemia 1999, 13, 1243-1253.

(27) Milkevitch, M.; Shim, H.; Pilatus, U.; Pickup, S.; Wehrle, J. P.; Samid, D.; Poptani, H.; Glickson, J. D.; Delikatny, E. J. Increases in NMRvisible lipid and glycerophosphocholine during phenylbutyrate-induced apoptosis in human prostate cancer cells. Biochim. Biophys. Acta 2005, $1734,1-12$

(28) Bieberich, E.; Hu, B.; Silva, J.; MacKinnon, S.; Yu, R. K.; Fillmore, H.; Broaddus, W. C.; Ottenbrite, R. M. Synthesis and characterization of novel ceramide analogs for induction of apoptosis in human cancer cells. Cancer Lett. 2002, 181, 55-64.

(29) Kuhajda, F. P. Fatty Acid Synthase and Cancer: New Application of an Old Pathway. Cancer Res. 2006, 66, 5977-5980.

(30) Menendez, J. A.; Lupu, R. Fatty acid synthase and the lipogenic phenotype in cancer pathogenesis. Nat. Rev. 2007, 7, 763-777.

JM8012807 